\title{
PENAMPAKAN KARAKTER AGRONOMI PADA 26 GENOTIPE PADI LOKAL KABUPATEN KUANTAN SINGINGI
}

\section{(Appearance Of Agronomic Characters In 26 Lokal Rice Genotypes In Kuantan Singingi Regency)}

\author{
Chairil Ezward $^{* 1}$, Elfi Indrawanis ${ }^{2}$, A.Haitami ${ }^{2}$, Wahyudi ${ }^{2}$ \\ ${ }^{1,2}$ Lecturer at the Agrotechnology Study Program \\ Faculty of Agriculture, Islamic University of Kuantan Singingi \\ "Corresponding Author, email : ezwardchairil@yahoo.com HP. 0852.6238.0410
}

Artikel Diterima 8 Oktober 2020, disetujui 2 Desember 2020

\begin{abstract}
ABSTRAK
Tanaman padi (Oryza sativa L.) merupakan tanaman pangan penting di Kabupaten Kuantan Singingi. Karena beras menjadi sumber bahan makanan pokok masyarakatnya. Tujuan dari penelitian ini adalah untuk mengetahui karakter agronomi 26 genotipe padi lokal Kabupaten Kuantan Singingi. Metode yang digunakan dalam penelitian ini adalah Rancangan Acak Kelompok (RAK) non Faktorial, terdiri dari 26 genotipe padi lokal sebagai perlakuannya. Hasil penelitian menunjukkan perlakuan 26 genotipe padi lokal berpengaruh nyata terhadap semua parameter pengamatan. Pada pengamatan jumlah anakan produktif, genotipe yang paling banyak jumlah anakan produktifnya terdapat pada genotipe PL25 (Saronda kuning) yaitu 11,49 batang. Pada pengamatan jumlah anakan hampa, genotipe yang paling sedikit jumlah anakan hampa adalah genotipe PL03 (Pandan wangi F4), PL10 (Limbayang), PL17 (Pulut kari) dan PL24 (Padi gondok) yaitu 0,24 batang. Pada pengamatan jumlah bulir permalai, yang paling banyak jumlah bulir permalai adalah genotipe PL09 (Samo putiah) yaitu 298,67 bulir. Pada pengamatan Berat Gabah Kering (gram/plot), genotipe yang paling berat adalah genotipe PL05 (Padi Ronda putiah) yaitu 102,19 (gram/plot). Pada pengamatan Berat Gabah Kering (ton/hektar), genotipe yang paling berat adalah genotipe PL05 (Padi Ronda putiah) yaitu 1,62 ton/hektar.
\end{abstract}

Kata kunci : Genotipe padi lokal, Kabupaten Kuantan Singingi, Karakter Agronomi.

\begin{abstract}
Abstrack
The rice plant is an important food crop in the Kuantan Singingi district. Bicause rice is a source of staple food. The purpose of this study was to determine the agronomic characters of 26 lokal rice genotypes of Kuantan Singingi Regency. The method used in this research is a non factorial randomized block design method, consisted of 26 local rice genotypes as treatment. The result showed that 26 local rice genotypes significantly affected all the observed parameters. On the observation, the highest number of productive tillers was PL25 (Saronda kuning) treatment, namly 11,49 stems. On the observation, the number of empty tillers was the least PL03 (Pandan wangi F4), PL10 (Limbayang), PL17 (Pulut kari) dan PL24 (Padi gondok) was 0,24 stems. In observation, the most number of bullets was PL09 (Samo putiah), namely 298,67. In the observation of dry grain weight (grams/plot) was PLO5 (Padi Ronda putiah) namely 102,19 grams/plot. In the observation of dry grain weight (tones/hectare) was PL05 (Padi Ronda putiah) namely 1,62 (tones/hectare).
\end{abstract}




\section{PENDAHULUAN}

Berdasarkan data Badan Pusat Statistik (2016), menyatakan bahwa jumlah penduduk Indonesia berdasarkan hasil Survei Penduduk Antar Sensus (SUPAS) tahun 2015 sebanyak 255,18 juta jiwa. Dibandingkan dengan sensus maupun survei penduduk sebelumnya, dapat dilihat bahwa jumlah penduduk Indonesia terus mengalami peningkatan. Dalam jangka waktu lima belas tahun yaitu tahun 2000 hingga 2015, jumlah penduduk Indonesia mengalami penambahan sekitar 50,06 juta jiwa atau rata-rata 3,33 juta setiap tahun (Gambar 1).

Penduduk Indonesia Tahun 2000- 2015 (Jutaan)

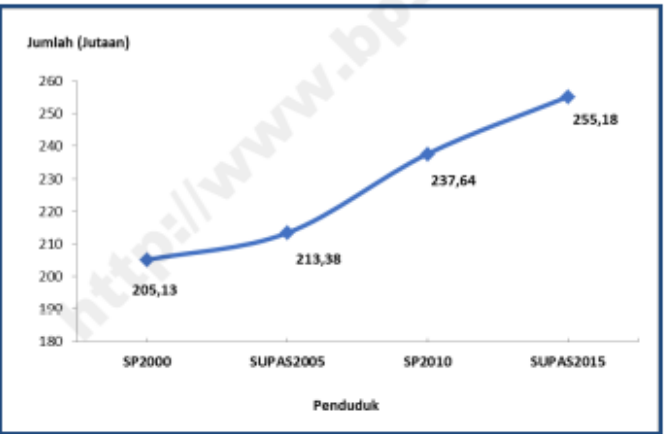

Sumber data: Sensus Penduduk 2000, 2010 dan SUPAS 2005, 2015

Gambar 1. Pertambahan jumlah penduduk Indonesia sekitar 50,06 juta jiwa atau rata-rata 3,33 juta setiap tahun (Jangka waktu lima belas tahun yaitu tahun 2000 hingga 2015)

Sementara di indonesia terjadi penurunan luas panen, produktivitas dan produksi. Pada tahun 2018, luas panen 11.377.934,44 hektar, di tahun 2019 luas panen turun menjadi 10.677.887,15 hektar. Pada tahun 2018 produktivitas 52,03 (ku/ha), pada tahun 2019 produktivitas turun menjadi 51,14 (ku/ha). Produksi pada tahun 2018 yaitu 59.200.533,72 ton, tahun 2019 produksi turun menjadi 54.604.033,34 ton (BPS, 2019).

Badan Pusat Statistik (2018), berdasarkan hasil Kerangka Sampel Area (KSA), luas panen padi di Indonesia periode Januari-September 2018 sebesar 9,54 juta hektar. Dengan memperhitungkan potensi sampai Desember 2018, maka luas panen tahun
2018 adalah 10,90 juta hektar. Produksi padi di Indonesia periode JanuariSeptember 2018 sebesar 49,65 juta ton Gabah Kering Giling (GKG). Berdasarkan potensi produksi sampai Desember 2018, maka diperkirakan total produksi padi tahun 2018 sebesar 56,54 juta ton GKG. Jika produksi padi dikonversikan menjadi beras dengan menggunakan angka konversi GKG ke beras tahun 2018, maka produksi padi tersebut setara dengan 32,42 juta ton beras.

Produksi padi dan produksivitas lahan yang rendah disebabkan oleh berbagai faktor. Sementara di sisi lain kebutuhan beras terus meningkat seiring pertambahan laju pertumbuhan penduduk. Peristiw ini menjadi masalah yang sangat serius untuk segera diselesaikan. Pertanyaannya : bagaimana bisa menyelesaikan masalah ini ?

Indonesia adalah negara Agraria yang berpotesi besar untuk mengembangkan pertanian. Indonesia terdiri dari wilayah yang berpotensi dalam pengembangan tanaman padi. Daerah atau wilayah tersebut menjadi lumbung padi yang membantu dalam menyediakan pasokan beras untuk daerah lain yang memiliki potensi dalam pengembangan komiditi pertanian selain padi.

Kab. Kuansing memilki areal sawah yang cukup luas. Menurut data Dinas Pertanian Kab. Kuansing (2019), berdasarkan jenis penggunaan lahan sawah Irigasi Setengah Teknis 2.745 hektar dan sawah tadah hujan 3.874 hektar. Produksi padi sawah pada tahun 2018 sebesar 23.989,76 ton Gabah Kering Panen (GKP), setara dengan $11.994,88$ ton beras. Karena satu (1) ton padi GKP setara dengan 0,5 ton beras.

Budidaya padi yang dilakukan oleh petani Kuantan Singingi biasa menggunakan benih padi (genotipegenotipe) lokal. Kebiasaan ini bukan tanpa alasan, petani menggunakan genotipe lokal karena kondisi sawah di Kuantan Singingi yang umumnya di tanam satu kali saja dalam satu tahun. Hal ini di lakukan 
karena tidak memadainya sistem perairan sawah petani (sebagian besar sawah tadah hujan). Genotipe lokal telah beradaptasi dengan kondisi yang seperti ini.

Sebagaian besar genotipe lokal tersebut belum di ketahui karakter agronominya. Karakter agronomi yang diperoleh dalam penelitian ini dalam bentuk data kuantitatif. Data kuantitatif tersebut bermanfaat sebagai infomasi dalam pemilihan penggunaan genotipe lokal sebagai bahan tanam.

Genotipe-genotipe lokal tersebut apabila telah teridentifikasi, maka akan diketahui sifat baiknya dan selanjutnya dapat digunakan sebagai sumber Plasma Nutfah dalam pengembangan Varietas Unggul Baru (VUB) di indinesia atau dapat pula sebagai bahan untuk diciptakannya varietas Unggul Lokal spesifik lokasi.

Sebagaimana di ketahui bahwa Indonesia memiliki keanekaragaman hayati dan Plasma Nutfah (PN) atau sumber daya genetik sangat besar. Sekitar $17 \%$ keseluruhan mahluk hidup terdapat di Indonesia (Muchtadi, 2006) dalam Febrialdi (2017).

Kab. Kuansing memiliki sumber Plasma Nutfah tanaman padi yang selanjutnya disebut genotipe. Namun genotipe padi tersebut belum teridentifikasi dengan baik.

Menurut Ezward, et al (2019), (Review Jurnal) mengatakan bahwa dalam upaya menyelesaikan masalah pada budidaya tanaman padi di Kab. Kuansing dapat dengan mengintegrasikan beberapa bidang ilmu dan melihat potensi lokal, seperti memanfaatkan benih genotipe padi lokal.

Masalah lainnya adalah keberadaan data produksi, data karakter morfologi, data kaakter molekuler genotipe padi lokal belum ada, oleh karena itu untuk mendapatkannya kegiatan yang harus dilakukan yaitu : mengeksplorasi genotipe padi lokal tersebut dan selanjutnya mengkarakterisasinya. Karakterisasi yang dapat dilakukan seperti karakterisasi, morfologi, molekuler dan agronomi.
Penelitian sebelumnya Ezward, et al (2020), telah mengidentifikasi karakter organ vegetatif beberapa genotipe padi lokal Kab. Kuansing. Pengolahan data untuk mendapatkan kekerabatannya menggunakan Sofwere NTSYS-pc version 2.02. Dimana menghasilkan enam (6) kelompok keberagaman pada koofisien kemiripan 30 persen.

Masih banyak kegitan karakterisasi lain yang harus dilakukan untuk mendapatkan data yang lengkap dari Identifikasi genotipe padi lokal Kab. Kuansing. Maka dari itu pada penelitian kali ini, peneliti melakukan karakterisasi agronomi, seperti pengamatan jumlah anakan produktif, jumlah anakan hampa, jumlah bulir permalai dan berat kering gabah.

\section{Perumusan Masalah}

Masalah yang akan dibahas dalam penelitian ini adalah belum terkarakterisasinya atau teridentifikasinya karakter agronomi genotipe - genotipe padi lokal Kabupaten Kuantan Singingi. Genotipe tersebut tidak sulit untuk diperoleh, karena selalu digunakan oleh petani setempat disetiap musim tanam. Namun data karakter agronomi genotipe tersebut masih banyak yang belum diketahui. Oleh karena itu perlu di ketahui karakter agronomi dari genotipe-genotipe padi lokal Kabupaten Kuantan Singingi.

\section{Tujuan Penelitian}

Mengetahui karakter agronomi 26 Genotipe Padi (Oryza sativa. L) Lokal Kabupaten Kuantan Singingi.

\section{Manfaat Penelitian}

Data dari hasil penelitian bisa digunakan sebagai bahan referensi untuk memilih benih genotipe yang akan digunakan dalam budidaya padi di Kab. Kuansing.

\section{METODOLOGI PENELITIAN}

\section{Tempat dan Waktu}

Penelitian ini dilaksanakan pada sawah irigasi di Desa Petapahan Kecamatan Gunung Toar. Penelitian ini 
berlangsung selama 6 bulan yang dimulai pada bulan Oktober 2019 sampai dengan Maret 2020.

\section{Bahan dan Alat}

Bahan yang digunakan dalam penelitian ini adalah 26 genotipe padi lokal Kabupaten Kuantan Singingi, pupuk kotoran ayam, pupuk Urea, TSP dan $\mathrm{KCl}$. Sedangkan alat yang digunakan yaitu cangkul, tali, meteran, sabit, kamera, dan alat tulis lainnya.

\section{Metode Penelitian}

Rancangan yang digunakan dalam penelitian ini adalah Rancangan Acak Kelompok (RAK) non Faktorial, yang terdiri dari 26 genotipe padi lokal Kabupaten Kuantan Singingi sebagai perlakuannya, yaitu :

Sironda putih (PL01), saronda merah (PL02), Pandan wangi F4 (PL03), pulut hitam (PL04), ronda putiah (PL05), singgaro merah (PL06), kuning umur panjang (PL07), padi ros (PL08), samo putiah (PL09), limbayang (PL10), pulut karate (PL11), sokan umur panjang (PL12), pulut benai Peboun Hulu (PL13), singgam putih (PL14), singgam kuriak (PL15), pulut solok (PL16), pulut kari (PL17), pulut benai Kinali (PL18), pulut kuning (PL19), padi adam (PL20), padi putih (PL21), lupo ka laki (PL22), padi kuning (PL23), Padi Gondok (PL24), saronda kuning (PL25), katiok putih (PL26).

Penelitian ini terdiri dari 26 perlakuan diulang 3 kali. Dengan demikian penelitian ini terdiri dari 78 unit percobaan/plot, setiap unit percobaan/plot terdiri dari 9 tanaman dan 7 diantaranya dijadikan sampel. Data hasil pengamatan dari masing-masing perlakuan dianalisis secara statistik dengan sidik ragam (ANSIRA). Apabila F hitung lebih besar dari $\mathrm{F}$ tabel maka dilakukan uji lanjut beda nyata jujur (BNJ) pada taraf $5 \%$.

\section{Analisis Statistik}

Data hasil penelitian yang diperoleh dari lapangan di analisis secara statistik sesuai dengan Rancangan Acak Kelompok
(RAK) Non Faktorial dengan rumus sebagai berikut :

$\mathrm{Y} \mathrm{ijk}=\mu+\mathrm{Pi}+\mathrm{Kk}+\varepsilon i \mathrm{k}$

Keterangan:

Yijk = Nilai pengamatan dari uji genotipe taraf ke-i pada ulangan ke-k

$\mu \quad=$ nilai tengah

$\mathrm{Pi}=$ Pengaruh faktor $\mathrm{P}$ pada taraf ke- $\mathrm{i}$

$\mathrm{Kk}=$ Pengaruh kelompok pada taraf ke$\mathrm{k}$

$(\mathrm{PT})=$ Pengaruh interaksi antara faktor $\mathrm{P}$ pada taraf ke-i

cik = Efek error faktor $\mathrm{P}$ pada taraf ke-i dan kelompok sampai ke-k

Keterangan :

$\mathrm{i}=0,1,2, \ldots . ., 26$ (Berbagai genotipe)

$\mathrm{k}=\mathrm{I}$, II, III (Kelompok/ulangan)

\section{Pelaksanaan Penelitian}

Pelaksanaan penelitian terdiri dari kegiatan-kegiatan sebagai berikut : persiapan dan pengelolaan lahan sawah, pembuatan plot $(1 \mathrm{~m} \times 1 \mathrm{~m})$, pemasangan label, persiapan bibit, penyeleksian benih, perendaman benih, pesemaian benih, pemberian pupuk dasar kotoran ayam, penanaman (3 bibit perlobang tanam), pemberian pupuk anorganik (pupuk kotoran ayam 20 ton perhekar), pemberian pupuk anorganik (Urea $200 \mathrm{~kg} /$ hektar, SP$36100 \mathrm{~kg} /$ hektar, $\mathrm{KCl} 50 \mathrm{~kg} /$ hektar), pemeliharaan (pengairan, penyulaman, penyiangan, pegendalian hama dan penyakit (Mengendalikan pianggang dengan insectisida, mengendalikan hama burung dengan memasang jaring), panen dan pengamatan.

\section{HASIL DAN PEMBAHASAN}

\section{Jumlah Anakan Produktif, Jumlah Anakan Hampa dan Jumlah Bulir Permalai}

Data hasil pengamatan terhadap parameter Jumlah Anakan Produktif, Jumlah Anakan Hampa dan Jumlah Bulir Permalai setelah dianalisis secara statistik sidik ragam menunjukkan berpengaruh nyata, dapat dilihat pada Tabel 1 . 
Tabel 1. Rerata Hasil Peneitian Jumlah Anakan Produktif, Jumlah Anakan Hampa dan Jumlah Bulir Permalai

\begin{tabular}{|c|c|c|c|}
\hline Genotipe & $\begin{array}{c}\text { Rerata } \\
\text { Jumlah } \\
\text { Anakan } \\
\text { Produktif }\end{array}$ & $\begin{array}{l}\text { Rerata } \\
\text { Jumlah } \\
\text { Anakan } \\
\text { Hampa }\end{array}$ & $\begin{array}{c}\text { Rerata } \\
\text { Jumlah Bulir } \\
\text { Permalai }\end{array}$ \\
\hline PL01 (Padi Sironda putih) & 7,06 cde & $0,38 \mathrm{ab}$ & 267,10 abcd \\
\hline PL02 (Padi Saronda merah) & 8,87 abcde & $0,29 \mathrm{a}$ & 258,24 abcde \\
\hline PL03 (Padi Pandan wangi F4) & 9,01 abcde & $0,24 \mathrm{a}$ & 220,52 abcdefgh \\
\hline PL04 (Pulut hitam) & 8,90 abcde & $0,48 \mathrm{ab}$ & $275,71 \mathrm{abc}$ \\
\hline PL05 (Padi Ronda putiah) & 8,98 abcde & $2,05 \mathrm{bc}$ & 209,48 bcdefgh \\
\hline PL06 (Padi Singgaro merah) & 7,73 bcde & $0,52 \mathrm{ab}$ & 222,95 abcdefgh \\
\hline PL07 (Padi Kuning umur panjang) & $9,79 \mathrm{abcd}$ & $2,71 \mathrm{c}$ & 182,52 efgh \\
\hline PL08 (Padi ros) & 7,65 bcde & $0,95 \mathrm{ab}$ & 208,05 bcdefgh \\
\hline PL09 (Padi Samo putiah) & 6,16 e & $0,33 \mathrm{ab}$ & $298,67 \mathrm{a}$ \\
\hline PL10 (Padi Limbayang) & 6,74 de & $0,24 \mathrm{a}$ & 237,62 abcdefgh \\
\hline PL11 (Pulut karate) & 8,41 abcde & $0,38 \mathrm{ab}$ & 195,05 cdefgh \\
\hline PL12 (Padi Sokan umur panjang) & 9,00 abcde & $0,57 \mathrm{ab}$ & 211,52 bcdefgh \\
\hline PL13 (Pulut benai Peboun Hulu) & 9,76 abcd & $1,10 \mathrm{abc}$ & $180,14 \mathrm{fgh}$ \\
\hline PL14 (Padi Singgam putih) & 9,12 abcde & $0,86 \mathrm{ab}$ & 228,81 abcdefgh \\
\hline PL15 (Padi Singgam kuriak) & 8,57 abcde & $0,38 \mathrm{ab}$ & $281,10 \mathrm{ab}$ \\
\hline PL16 (Pulut solok) & 9,50 abcde & $0,29 \mathrm{a}$ & 252,33 abcdef \\
\hline PL17 (Pulut kari) & $10,30 \mathrm{abc}$ & $0,24 \mathrm{a}$ & $179,52 \mathrm{fgh}$ \\
\hline PL18 (Pulut benai Kinali) & $11,08 \mathrm{ab}$ & $0,48 a b$ & 190,14 defgh \\
\hline PL19 (Padi kuning copek, Kinali) & 7,58 bcde & $2,05 \mathrm{bc}$ & $267,52 \mathrm{abcd}$ \\
\hline PL20 (Padi adam) & $10,76 \mathrm{ab}$ & $0,52 \mathrm{ab}$ & $167,00 \mathrm{gh}$ \\
\hline PL21 (Padi putih) & 9,68 abcde & $2,71 \mathrm{c}$ & 245,24 abcdefg \\
\hline PL22 (Pulut Lupo ka laki) & 9,27 abcde & $0,95 \mathrm{ab}$ & $159,24 \mathrm{~h}$ \\
\hline PL23 (Padi kuning) & 8,98 abcde & $0,33 \mathrm{ab}$ & $277,62 \mathrm{abc}$ \\
\hline PL24 (Padi gondok) & 9,22 abcde & $0,24 \mathrm{a}$ & 238,00 abcdefgh \\
\hline PL25 (Padi Saronda kuning) & $11,49 \mathrm{a}$ & $0,38 \mathrm{ab}$ & $166,00 \mathrm{gh}$ \\
\hline \multirow[t]{2}{*}{ PL26 (Padi Katiok putih) } & 8,30 abcde & $0,57 \mathrm{ab}$ & 249,00 abcdefg \\
\hline & $\begin{array}{c}\mathrm{KK}=12,42 \% \\
\mathrm{BNJ}=10,57\end{array}$ & $\begin{array}{c}\mathrm{KK}=69,80 \% \\
\mathrm{BNJ}=1,73\end{array}$ & $\begin{array}{c}\mathrm{KK}=11,59 \% \\
\mathrm{BNJ}=83,19\end{array}$ \\
\hline
\end{tabular}

Angka-angka pada kolom dan baris yang diikuti huruf kecil yang sama menunjukkan berbeda tidak nyata menurut BNJ pada taraf 5\%..

Selajutnya penampakan hasil pengamatan terhadap parameter Jumlah Anakan Produktif yang telah dianalisis secara statistik sidik ragam menunjukkan berpengaruh nyata, dapat pula dilihat dalam bentuk Grafik. Penampakan Jumlah Anakan Produktif terbaik dapat dilihat pada Grafik 1. 


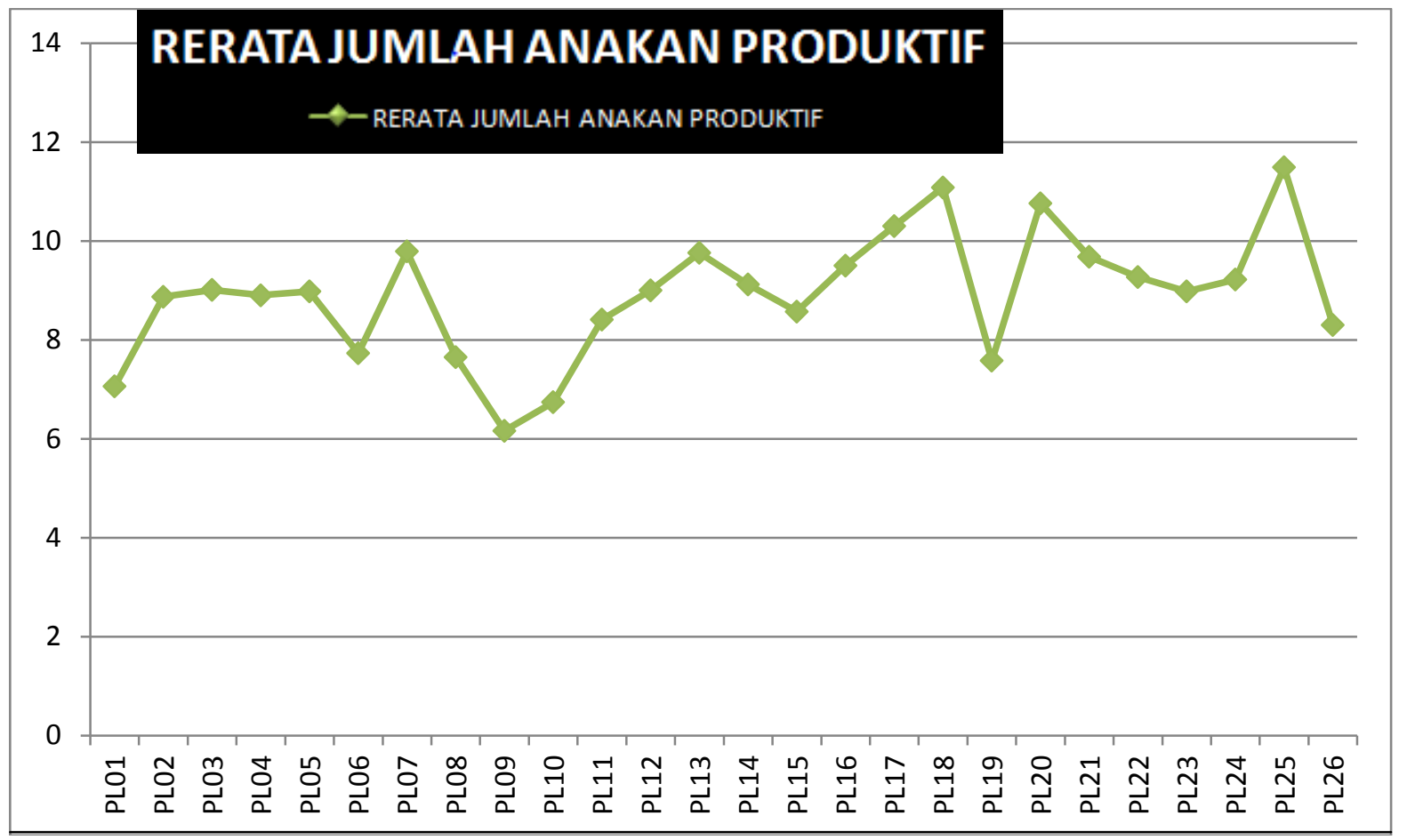

Berdasarkan Tabel 1, menunjukkan bahwa perlakuan genotipe memberikan pengaruh yang nyata terhadap jumlah anakan produktif. Dimana setelah di uji lanjut dengan beda nyata jujur pada taraf $5 \%$, menunjukkan bahwa masing-masing genotipe ada yang menunjukkan berbeda nyata dan ada juga yang menunjukan tidak berbeda nyata. Genotipe yang paling banyak jumlah anakan produktifnya terdapat pada genotipe PL25 (Saronda kuning) yaitu 11,49 anakan. sedangkan yang paling sedikit terdapat pada genotipe PL09 (Samo putiah) yaitu 6,16 anakan.

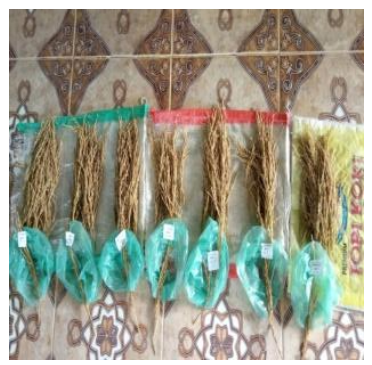

Gambar 2. Hasil pengamatan dan perhitungan Jumlah anakan produktif
Apabila dibandingkan dengan jumlah anakan produktif varietas Cisokan yaitu berkisar 20-25 batang, jumlah anakan produktif varietas IR64 berkisar 20-35 batang, jumlah anakan produktif varietas IR66 berkisar 14 - 17 batang, jumlah anakan produktif varietas batang piaman berkisar 14-19 batang (Suprihatno, Daradjat, Satoto, Baehaki, Widiarta, Agus, Dewi, Ooy dan Sembiring, 2009). Maka jumlah anakan produktif genotipe lokal Kabupaten Kuantan Singingi cukup mendekati jumlah anakan produktif varietas unggul. Oleh karena itu genotipe lokal Kabupaten Kuantan Singingi dapat dikembangkan lebih lanjut.

Perbedaan jumlah anakan produktif, hal ini disebabkan oleh sifat genetik yang dimiliki oleh masing-masing genotipe yang digunakan dalam penelitian. Sifat genetik masing-masing genotipe yang merespons lingkungan yang telah dianggap sama. Karena lingkungan apabila berbeda-beda akan mempengaruhi tampilan genetiknya juga akan berbeda. Jadi jumlah anakan produktif yang berbeda 
lebih dipengaruhi oleh sifat genetik dari masing-masing genotipe.

Menurut Cepy dan Wayan (2011) tinggi rendahnya pertumbuhan serta hasil tanaman dipengaruhi oleh 2 faktor yaitu internal yang meliputi sifat genetik atau turunan tanaman dan eksternal yaitu faktor lingkungan seperti iklim tanah dan faktor biotik. Perbedaan jumlah anakan masingmasing kultivar diduga karana pengaruh faktor-faktor tersebut. Hal tersebut sejalan dengan hasil penelitian dari Anhar et al. (2016) yang menyatakan bahwa jumlah anakan dan tinggi tanaman yang berbeda dikarenakan setiap varietas memiliki sifat gen yang berbeda-beda. Sistem tanam langsung menghasilkan anakan yang lebih sedikit dari pada sistem tanam pindah. Anakan tersier tidak begitu diinginkan karena hanya akan menghasilkan pertumbuhan malai yang terlambat masak dan kalah bersaing dengan anakan primer dan sekunder (Manurung dan Ismunadji, 1988).

Berdasarkan jumlah anakan yang terbentuk, dapat dikatakan bahwa genotipe yang digunakan dalam penelitian ini memiliki kemampuan beranak rendah sampai sedang, sesuai dengan Rice Standard Evaluation System yaitu sangat tinggi (>25 anakan/tanaman), tinggi (20-25 anakan/tanaman), sedang (10-19 anakan/tanaman), rendah (5-9 anakan/tanaman), sangat rendah $\quad(<5$ anakan/tanaman) (IRRI, 2002).

Hal ini merupakan potensi yang dapat dikembangkan dengan sistem pemuliaan konvensional, pemuliaan modern ataupun bioteknologi tanaman. Sehingga potensi potensi sifat genetik genotipe lokal padi asal Kuantan Singingi dapat dimanfaatkan dan berdampak positif bagi pertanian di Kabupaten Kuantan Singingi, khususnya pengembangan budidaya tanaman padi.

Berdasarkan Tabel 1, data rerata Parameter Jumlah Anakan Hampa setelah di analisis secara statistik sidik ragam menunjukkan berpengaruh nyata. Selanjutnya di uji lanjut dengan beda nyata jujur pada taraf 5\%, menunjukkan bahwa masing-masing genotipe ada yang menunjukkan berbeda nyata dan ada juga yang menunjukan tidak berbeda nyata. Genotipe yang paling sedikit adalah genotipe PL03 (Pandan wangi F4), PL10 (Limbayang), PL17 (Pulut kari) dan PL24 (Padi gondok) yaitu 0,24 anakan. Sedangkan yang paling banyak adalah genotipe PL07 (Kuning umur panjang) dan PL21 (Padi putih) yaitu 2,71 anakan.

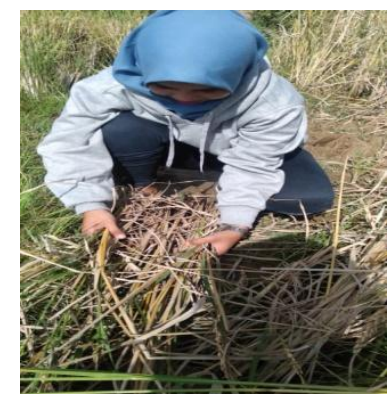

Gambar 3. Pengamatan dan perhitungan Jumlah anakan

Apabila dilihat dari masing-masing genotipe, sedikit sekali jumlah anakan hampa dari hasil penelitian. Sebagaimana diketahui, anakan hampa dapat di sebabkan oleh 2 faktor, yang pertama adalah suhu dan panas cahaya patahari pada fase pembentukan bunga. Apabila terlalu panas, maka akan banyak terbentuk bunga hampa. Faktor kedua adalah pianggang atau walangsangit. Hama ini menyerang bunga tanaman padi ketika pada fase masak susu. Hama ini menghisap cairan yang ada pada malai yang masih dalam bentuk cairan putih susu.

Tidak hanya pada sistem konvensional cahaya mempengaruhi pembungaan dan akan berpengaruh langsung kepada produktivitas, sistem jejar legowo dan sistem SRI juga memiliki prinsip pencahayaan dengan mengatur jarak tanam. Hal ini sesuai dengan Nurlaili (2011), yang mengatakan bahwa penerimaan cahaya optimum yang diperlukan tanaman padi pola SRI berpengaruh pada pertumbuhan sehingga akan memberikan produktivitas yang tinggi bagi tanaman. 
Menurut Nofiardi, Sarbino dan Fadjar (2016), telah melakukan penelitian yang bertujuan untuk mengukur perubahan populasi walang sangit, kerusakan dan penurunan hasil akibat serangan walang sangit. Penelitian dilaksanakan di Desa Sejiram Kecamatan Tebas Kabupaten Sambas. Lama penelitian 2 bulan dari bulan Mei sampai Juni 2016. Penelitian dilakukan dengan pendekatan survei. Populasi walang sangit ditentukan pada pengayunan di petak pengamatan di tiga sawah dengan agroekosistem yang berbeda, yaitu padi monokultur, tumpang sari padi dengan jeruk dan tumpang sari padi dengan karet. Penangkapan walang sangit dilakukan pada luasan petak pengamatan $1 \mathrm{~m} 2$ dengan 5 kali ulangan yaitu 17 MST, 18 MST, 19 MST, 20 MST dan 21 MST. Variabel pengamatan meliputi jumlah populasi walang sangit pada semua periode penangkapan, jumlah bulir padi rusak atau hampa dan berat bulir per petak pengamatan. Hasil penelitian menunjukkan populasi walang sangit tertinggi terjadi pada $18 \mathrm{MST}$, saat padi sedang mengalami fase pembungaan dan matang susu. Populasi tertinggi terdapat pada sawah tumpang sari padi dengan karet sebesar 18 individu per petak dan terendah pada padi monokultur sebesar 13,8 individu per petak. Populasi walang sangit pada fase tersebut yang akan menyebabkan kerusakan bulir padi pada saat panen. Keparahan serangan walang sangit belum menampakan penurunan hasil pada tiap sawah pengamatan dikarenakan perbedaan varietas dan cara pengelolaannya.

Namun pada penelitian pengendalian hama terpadu telah dilakukan dengan maksimal. Sehingga dapat menekan serangan hama pianggang. Berarti jumah anakan hampa dipengaruhi oleh suhu dan panas. Karena jumlah anakan hampa sedikit, berarti genotipe padi lokal asal Kuantan Singingi yang sejarahnya berasal dari turunan varietas unggul pada tahun 1978 oleh Program Pemerintah (BIMAS) telah benar-benar berdadaptasi dan melakukan evolusi dengan lingkungan Kabupaten Kuantan Singingi. Jumlah anakan hampa yang sedikit menunjukan nilai yang baik. Sehingga dapat juga sebagai bahan pertimbangan dalam pengembangan genotipe lokal asal Kabupaten Kuantan Singingi ke depannya.

Berdasarkan Tabel 1, data rerata Parameter Jumlah Bulir Permalai setelah dianalisis secara statistik sidik ragam menunjukkan berpengaruh nyata. Selanjutnya di uji lanjut dengan beda nyata jujur pada taraf 5\%, menunjukkan bahwa masing-masing genotipe ada yang menunjukkan berbeda nyata dan ada juga yang menunjukan tidak berbeda nyata. Genotipe yang paling banyak adalah genotipe PL09 (Samo putiah) yaitu 298,67 bulir. Sedangkan yang paling sedikit adalah genotipe PL22 (Lupo ka laki) yaitu 159,24 bulir.

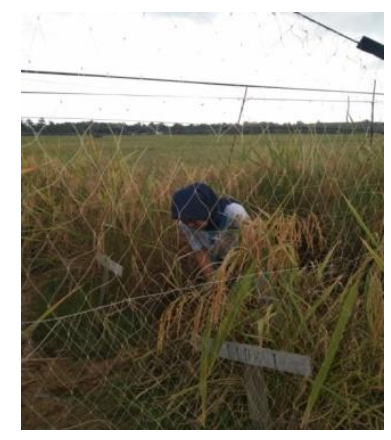

Gambar 4. Panen

Ketiga parameter pengamatan menunjukan berpengaruh nyata dan berbeda atau tidak berbeda disebabkan oleh setiap genotipe memiliki sifat yang berbeda. Hal ini disebabkan oleh sifat dan karakter dari masing masing genotipe. Setiap genotipe akan menunjukan karakternya berdasarkan sifat-sifat dari gen yang dimilikinya dan merespon lingkungannya. Hal ini sesuai dengan Mangoendidjojo (2003), yang mangatakan bahwa variasi atau perbedaan yang berasal dari suatu genotipe atau individu, merupakan dampak dari responnya terhadap kondisi lingkungan yang sama. 
Faktor genetik merupakan penentu perbedaan dari keberagaman karakter yang di tunjukan dari genotipe-genotipe yang berbeda. Hal ini sesuai dengan pendapat Sadjad (1993) yang mengatakan, bahwa faktor genetiknya merupakan penentu terjadinya perbedaan daya tumbuh dari suatu varietas.

Tampilan fisiologis maupun morfologis dari genotipe-genotipe yang berbeda merupakan respon gen terhadap kondisi lingkungan. Hal ini sesuai dengan pendapat Jumin (2005) yang mengatakan, bahwa perubahan fisiologis dan morfologis tanaman adalah dampak dari penyesuaian diri dengan lingkungannya.

Penampakan dari bentuk maupun suatu karakter dari genotipe-genotipe yang digunakan pada penelitian ini disebabkan oleh faktor genetiknya yang menanggapi kondisi lingkungan yang sama. Hal ini sesuai dengan pendapat Harjadi (1991) yang menyetakan, bahwa beberapa varietas apabila ditanam pada kondisi yang sama akan menunjukan pertumbuhan dan hasil yang berbeda.

\section{Berat Gabah Kering}

Data hasil pengamatan terhadap parameter Berat Gabah Kering (gram/plot) dan Berat Gabah Kering (ton/hektar) setelah dianalisis secara statistik sidik ragam menunjukkan berpengaruh nyata, dapat dilihat pada Tabel 2.

Tabel 2. Rerata Hasil Penelitian Berat Gabah Kering (gram/plot) dan Berat Gabah Kering (ton/hektar)

\begin{tabular}{lccc}
\hline \multicolumn{1}{c}{ Genotipe } & $\begin{array}{c}\text { Keterangan } \\
\text { (Beras atau } \\
\text { Pulut) }\end{array}$ & $\begin{array}{c}\text { Rerata Berat } \\
\text { Gabah Kering } \\
\text { (gram/plot) }\end{array}$ & $\begin{array}{c}\text { Rerata Berat } \\
\text { Gabah Kering } \\
\text { (ton/Ha) }\end{array}$ \\
\hline PL01 (Padi Sironda putih) & Beras & $86,14 \mathrm{ab}$ & $1,37 \mathrm{ab}$ \\
PL02 (Padi Saronda merah) & Beras & $100,48 \mathrm{a}$ & $1,59 \mathrm{ab}$ \\
PL03 (Padi Pandan wangi F4) & Beras & $78,81 \mathrm{ab}$ & $1,25 \mathrm{ab}$ \\
PL04 (Pulut hitam) & Pulut & $83,52 \mathrm{ab}$ & $1,33 \mathrm{ab}$ \\
PL05 (Padi Ronda putiah) & Beras & $102,19 \mathrm{a}$ & $1,62 \mathrm{a}$ \\
PL06 (Padi Singgaro merah) & Beras & $79,43 \mathrm{ab}$ & $1,26 \mathrm{ab}$ \\
PL07 (Padi Kuning umur panjang) & Beras & $77,86 \mathrm{ab}$ & $1,24 \mathrm{ab}$ \\
PL08 (Padi ros) & Beras & $78,38 \mathrm{ab}$ & $1,24 \mathrm{ab}$ \\
PL09 (Padi Samo putiah) & Beras & $83,43 \mathrm{ab}$ & $1,32 \mathrm{ab}$ \\
PL10 (Padi Limbayang) & Beras & $88,90 \mathrm{ab}$ & $1,41 \mathrm{ab}$ \\
PL11 (Pulut karate) & Pulut & $74,24 \mathrm{ab}$ & $1,18 \mathrm{ab}$ \\
PL12 (Padi Sokan umur panjang) & Beras & $94,00 \mathrm{ab}$ & $1,49 \mathrm{ab}$ \\
PL13 (Pulut benai Peboun Hulu) & Pulut & $75,76 \mathrm{ab}$ & $1,20 \mathrm{ab}$ \\
PL14 (Padi Singgam putih) & Beras & $100,10 \mathrm{a}$ & $1,59 \mathrm{ab}$ \\
PL15 (Padi Singgam kuriak) & Beras & $86,48 \mathrm{ab}$ & $1,37 \mathrm{ab}$ \\
PL16 (Pulut solok) & Pulut & $59,76 \mathrm{~b}$ & $0,95 \mathrm{~b}$ \\
PL17 (Pulut kari) & Pulut & $83,05 \mathrm{ab}$ & $1,32 \mathrm{ab}$ \\
PL18 (Pulut benai Kinali) & Pulut & $72,86 \mathrm{ab}$ & $1,16 \mathrm{ab}$ \\
PL19 (Padi kuning copek, Kinali) & Beras & $82,33 \mathrm{ab}$ & $1,31 \mathrm{ab}$ \\
PL20 (Padi adam) & Beras & $59,48 \mathrm{~b}$ & $0,94 \mathrm{~b}$ \\
PL21 (Padi putih) & Beras & $78,24 \mathrm{ab}$ & $1,24 \mathrm{ab}$ \\
& & &
\end{tabular}




\begin{tabular}{llcc} 
PL22 (Pulut Lupo ka laki) & Pulut & $73,57 \mathrm{ab}$ & $1,17 \mathrm{ab}$ \\
PL23 (Padi kuning) & Beras & $83,81 \mathrm{ab}$ & $1,33 \mathrm{ab}$ \\
PL24 (Padi gondok) & Beras & $86,71 \mathrm{ab}$ & $1,38 \mathrm{ab}$ \\
PL25 (Padi Saronda kuning) & Beras & $83,14 \mathrm{ab}$ & $1,32 \mathrm{ab}$ \\
PL26 (Padi Katiok putih) & Beras & $74,24 \mathrm{ab}$ & $1,18 \mathrm{ab}$ \\
\hline & & KK $=15,77 \%$ & KK $=15,78 \%$ \\
& & BNJ 39,94 & BNJ = 0,65 \\
\hline
\end{tabular}

Angka-angka pada kolom dan baris yang diikuti huruf kecil yang sama menunjukkan berbeda tidak nyata menurut BNJ pada taraf 5\%..

Berdasarkan Tabel 2 dan Grafik 2, menunjukkan bahwa perlakuan genotipe memberikan pengaruh yang nyata terhadap Berat Gabah Kering (ton/hektar). Dimana setelah di uji lanjut dengan beda nyata jujur pada taraf $5 \%$, menunjukkan bahwa masing-masing genotipe ada yang menunjukkan berbeda nyata dan ada juga yang menunjukan tidak berbeda nyata. Genotipe yang paling berat hasil Berat Gabah Keringnya terdapat pada genotipe PL05 (Padi Ronda putiah) yaitu 1,62 ton/hektar, sedangkan yang paling ringan terdapat pada genotipe PL20 (Padi adam) yaitu 0,94 ton/hektar.

Berdasarkan Tabel 2, data rerata Berat Gabah Kering (gram/plot) setelah di analisis secara statistik sidik ragam menunjukkan berpengaruh nyata.
Selanjutnya di uji lanjut dengan beda nyata jujur pada taraf 5\%, menunjukkan bahwa masing-masing genotipe ada yang menunjukkan berbeda nyata dan ada juga yang menunjukan tidak berbeda nyata. Genotipe yang paling berat adalah genotipe PL05 (Padi Ronda putiah) yaitu 102,19 (gram/plot), sedangkan yang paling ringan adalah genotipe PL20 (Padi adam) yaitu 59,48 (gram/plot).

Selajutnya penampakan hasil pengamatan terhadap parameter Rerata Berat Gabah Kering (ton/Hektar) yang telah dianalisis secara statistik sidik ragam menunjukkan berpengaruh nyata, dapat pula dilihat dalam bentuk Grafik. Penampakan Rerata Berat Gabah Kering (ton/Hektar) terbaik dapat dilihat pada Grafik 2.

Grafik 2. Rerata Berat Gabah Kering (ton/Hektar) dengan perlakuan Genotipe

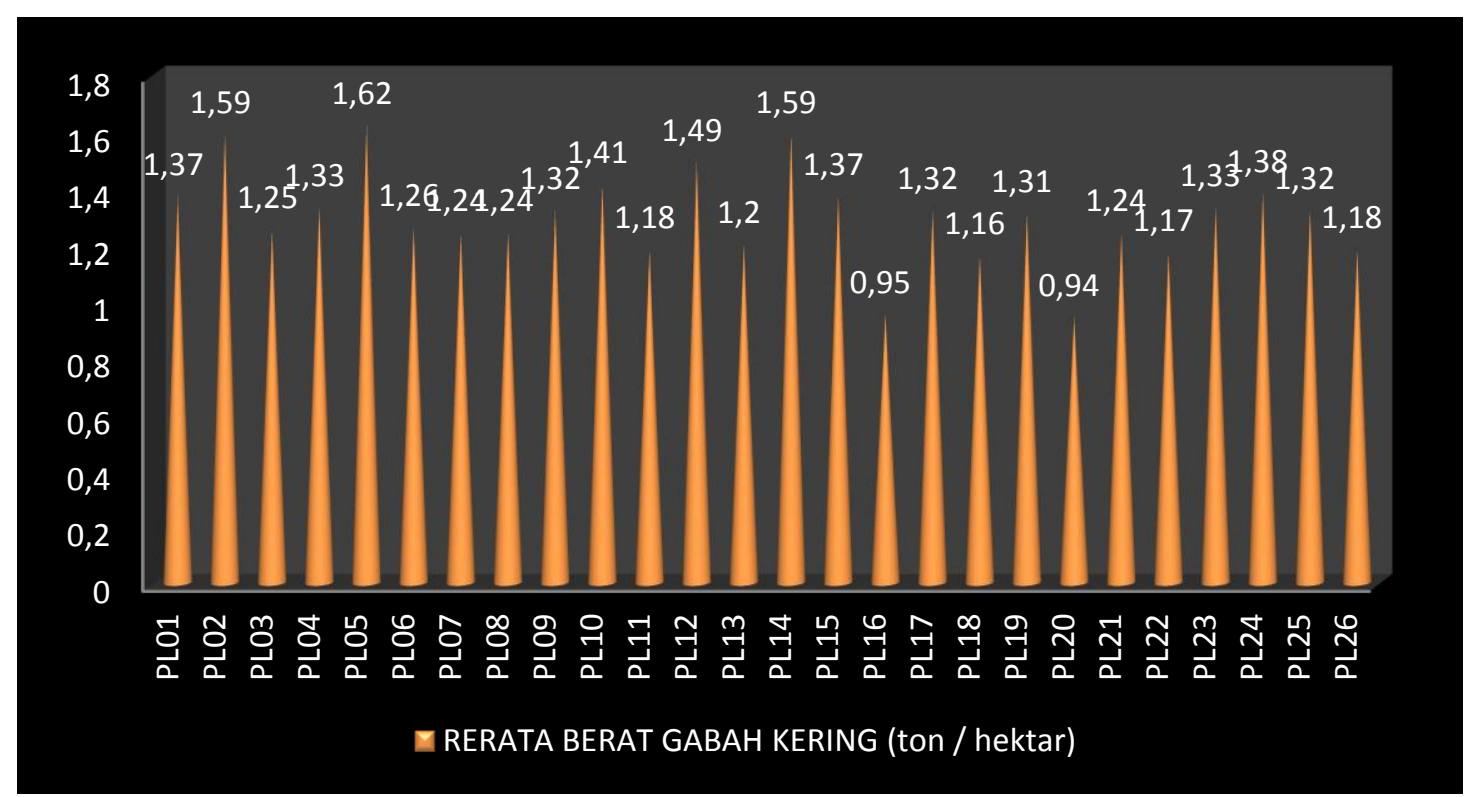


Apabila dibandingkan dengan Berat Gabah Kering varietas Cisokan rata - rata hasil 4,5 ton/hektar dan potensi hasil 6 ton/hektar, Berat Gabah Kering varietas IR42 rata - rata hasil 5 ton/hektar dan potensi hasil 7 ton/hektar, Berat Gabah Kering varietas IR66 rata - rata hasil 4,5 ton/hektar dan potensi hasil 5,5 ton/hektar, Berat Gabah Kering varietas IR64 rata rata hasil 5 ton/hektar dan potensi hasil 6 ton/hektar, Berat Gabah Kering varietas batang piaman rata - rata hasil 6 ton/hektar dan potensi hasil 7,6 ton/hektar (Suprihatno, Daradjat, Satoto, Baehaki, Widiarta, Agus, Dewi, Ooy dan Sembiring, 2009). Maka Berat Gabah Kering (ton/hektar) genotipe lokal Kabupaten Kuantan Singingi masih jauh dari hasil Berat Gabah Kering varietas unggul. Oleh karena itu genotipe lokal Kabupaten Kuantan Singingi perlu sentuhan teknologi pemuliaan untuk bisa dikembangkan menjadi lebih baik lagi.

Semua parameter pengamatan menunjukan berpengaruh nyata dan berbeda atau tidak berbeda nyata disebabkan oleh masing - masing genotipe yang digunakan dalam penelitian memiliki sifat dalam merespon kondisi lingkungan yang sama, namun sifat genetiknya menunjukan respon yang berbeda-beda. Karakter atau tampilan baik fisiologis maupun morfologis dari setiap genotipe yang digunakan berbeda-beda, maka akan mempengaruhi hasil yang berbeda pula. Genotipe sendiri memiliki pengertian yaitu ciri-ciri fisik yang tidak tampak maupun yang tampak dapat disebabkan oleh evolusi pada suatu organisme yang bersangkutan dengan susunan genetik (DNA).

Perubahan atau tampilan yang berbeda dari masing-masing genotipe yang ditanam pada lingkungan yang sama, maka perbedaan-perbedaan tersebut yang mengendalikannya lebih besar adalah sifat genetiknya (DNA). Wahyuni (2008) dalam Yulina (2020), mengatakan bahwa penggunaan benih dari genotipe yang berbeda akan memberikan potensi yang berbeda dan perbedaan ini aan menimbulkan keberagaman penampilan.

Sudjijo dan Saipinus (1995), menyatakan bahwa penggunaan benih dan cara bercocok tanam serta lahan yang tepat dapat mempengaruhi produksi, baik secara kualitas maupun Kuantitas. Simatupang (1997), menyatakan bahwa tingginya produksi suatu varietas dikarenakan varietas tersebut mampu beradaptasi dengan lingkungannya.

Gardner et al (1991), menyatakan bahwa faktor internal perangsang pertumbuhan tanaman berada dalam kendali genetik, tetapi unsur-unsur iklim, tanah dan biologi seperti hama, penyakit dan gulma serta persaingan, baik persaingan intraspesies maupun antar spesies ada pada lingkungannya.

\section{KESIMPULAN}

Perlakuan 26 genotipe padi lokal berpengaruh nyata terhadap semua parameter pengamatan. Pada pengamatan jumlah anakan produktif, genotipe yang paling banyak jumlah anakan produktifnya terdapat pada genotipe PL25 (Saronda kuning) yaitu 11,49 anakan. Pada pengamatan jumlah anakan hampa, genotipe yang paling sedikit jumlah anakan hampa adalah genotipe PL03 (Pandan wangi F4), PL10 (Limbayang), PL17 (Pulut kari) dan PL24 (Padi gondok) yaitu 0,24 anakan. Pada pengamatan jumlah bulir permalai, yang paling banyak jumlah bulir permalai adalah genotipe PL09 (Samo putiah) yaitu 298,67 bulir. Pada pengamatan Berat Gabah Kering (gram/plot), genotipe yang paling berat adalah genotipe PL05 (Padi Ronda putiah) yaitu 102,19 (gram/plot). Pada pengamatan Berat Gabah Kering (ton/hektar), genotipe yang paling berat adalah genotipe PL05 (Padi Ronda putiah) yaitu 1,62 ton/hektar.

\section{DAFTAR PUSTAKA}

Anhar, R., H. Erita. dan Efendi. 2016. Pengaruh dosis pupuk urea 
terhadap pertumbuhan dan produksi plasma nutfah padi lokal asal Aceh. Jurnal Kawista. 1(1): 30-36

Badan Pusat Statistik. 2018. Ringkasan Eksekutif Luas Panen dan Produksi Beras di Indonesia 2018 "Executive Summary 2018 Harvested Area and Rice Production in Indonesia". Badan Pengkajian dan Penerapan Teknologi Badan Pusat Statistik. Jakarta-Indonesia. Hal 7.

Badan Pusat Statistik. 2019.

https://jateng.bps.go.id/ news/ 2019/ 09/19/293/kira-kira-berapaya-jumlah-penduduk-indonesiadi- tahun - 2020 -. html

Badan Pusat Statistik (BPS). 2019. Luas Panen, Produksi, dan Produktivitas Padi Menurut Provinsi, 2018-2019. Badan Pusat Statistik. Jakarta-Indonesia, Hal 1.

https://www.bps.go.id/dynamicta ble/2019/04/15/1608/luas-panenproduksi-dan-produktivitas-padimenurut-provinsi-2018.html. di unduh tanggal 28 Februari 2020

Cepy dan W. Wayan. 2011. Pertumbuhan dan hasil tanaman padi (Oryza sativa L.) di media vertisol dan entisol pada berbagai teknik pengaturan air dan jenis pupuk. Jurnal Crop Agro 4(2): 49-56

Dinas Tanaman Pangan Kabupaten Kuantan Singingi. 2014. Laporan Tahunan. Kabupaten Kuantan Singingi

Dinas Pertanian Kabupaten Kuantan Singingi. 2019. Laporan Tahunan. Dinas Pertanian Kabupaten Kuantan Singingi

Ezward. C, Irfan. S, Nalwida. R, Indra. D. 2019. Upaya Pengembangan Genotipe Padi Lokal Kabupaten Kuantan Singingi. Jurnal Sains Agro. Vol. 4. No. 2. (Artikel review)
Ezward. C, Irfan. S, Nalwida. R, Indra. D. 2020. Identifikasi karakter vegetatif Beberapa genotipe padi lokal Kabupaten kuantan singingi. Jurnal Menara Ilmu. Vol. 14, No. 2 Hal : 12-22.

Febrialdi. A. 2017. Kondisi Beberapa Plasma Nutfah Non Kayu Disekitar Hutan Kecamatan Rantau Pandan muaro Bungo. Jurnal Sains Agro. Vol 2 Nomor 1.

Gardner, F, P., R. B. Pearce dan R.I. Mitchell. 1991. Fisiologi Tanaman Budidaya. Universitas Indonesia Press. Jakarta

Hairmansis A., Aswidinnor H., Trikoesooemangtyas, dan Suwarno. (2005). Evaluasi daya pemulih kesuburan padi lokal dari kelompok tropical japonica. Bogor, Buletin Agron (33) : 1-6

Hanum. C. 2008. Teknik Budidaya Tanaman. Direktorat Pembinaan Sekolah Menengah Kejuruan. Jakarta

Harjadi, S, S, M, M. 1991. Pengantar Agronomi. PT. Gramedia. Jakarta

Hasanah,I. 2007. Bercocok Tanam Padi. Azka Mulia Media. Jakarta.

Herawati, W.D 2012. Budidaya Padi. Javalitera . Jogyakarta

International Rice Research Institute[IRRI]. 2002. Rice standard evaluation system. [diunduh 16 Agustus 2020] Tersedia pada http://www.knowledgebang.irri.or $\mathrm{g}$

Iskandar J. 2001. Manusia, Budaya, dan Lingkungan: Kajian Ekologi Manusia. Humaniora Utama Press. Bandung

Istiyastuti, dan T Yanuharso. 1996. Berbudi Daya aneka Tanaman Pangan. Trigenda Karya. Bandung. $108 \mathrm{Hal}$

Jumin, H, B. 2005. Dasar-dasar Agronomi Edisi Refisi. PT. Raja Grafindo Persada. Jakarta 
Kafisa, S. 2016. Uji Perbedaan Sistem Jajar Legowo Terhadap Beberapa Varietas Tanaman Padi (Oryza sativa L.) Pada Sawah Tadah Hujan. Skripsi. Fakultas Pertanian Universitas Sumatra Utara. Medan.

Mangoendidjojo, W. 2003. Dasar-dasar Pemuliaan Tanaman. Yogyakarta

Manurung, S.O. dan M. Ismunadji. 1988. Padi : Morfologi dan fisiologi padi. Badan Penelitian dan Pengembangan Pertanian, Pusat Penelitian dan Pengembangan Tanaman Pangan. Bogor

Muchtadi, T.R. 2006. Kebijakan Ristek dalam Meningkatkan Kegiatan Penelitian Keanekaragaman Hayati. Lokakarya Nasional "Keanekaragaman Hayati di Ujung Tanduk". Organisasi Profesi Ilmiah dan LIPI. Jakarta, 18-19 Desember 2006

Nafisah, A.A. Daradjat, B. Suprihatno, dan Triny S.K. 2007. Heritabilitas karakter ketahanan hawar daun bakteri dari tiga populasi tanaman padi hasil seleksi daur siklus pertama. Jurnal Penelitian Pertanian Tanaman Pangan 26(2): 100-105

Nofiardi. E, Sarbino, Fadjar.R. 2016. Fluktuasi Populasi dan Keparahan Serangan Walang Sangit (Leptocorisa oratorius F.) pada Tanaman Padi di Desa Sejiram Kecamatan Tebas Kabupaten Sambas. Jurnal Sains Mahasiswa Pertanian Untan. Jurnal yang diterbitkan oleh Universitas Tanjungpura. Volume 5 Nomor 2. Hlm : 1-10

Norsalis E. 2011.Padi Gogo Dan Padi Sawah. Diakses dari http://repository.usu.ac.id/bitstrea $\mathrm{m} / 123$

456789/17659/4/Chapter\%20II.pd

f. Pada 5 Desember 2011.

Nurlaili. 2011. Optimalisasi Cahaya Matahari pada Pertanaman Padi
(Oryza sativa L.) System of Rice Intensification (SRI) Melalui Pendekatan Pengaturan Jarak Tanam. Agronobis. 3 (5): 22-27.

Plantamor, 2008. Tanaman http:/ /www. plantamor. com/ indeks.php? plant $=(926)(2008)$ Diakses pada tanggal 7 mei 2012

Purwasasmita.2012 Padi SRI Organik Indonesia. Penebar Swadaya. Jakarta. 136-138 hal.

Rahayu, T. 2009. Budidaya Tanaman Padi dengan Teknologi MiG-6 plus. BPP Teknologi dan Mig Plus.

Riau Online, BeritaTaluk Kuantan. 2020. https://www.riauonline.co.id/ riau/ rantau-kuantan/ read/ 2019/ 12/ 03/ dinas-pertanian-kuansingsalurkan-51.6543-benih-padi, di unduh 09 oktober 2020

Sadjad, S. 1993. Kuantifikasi Metabolisme Benih. PT. Gramedia. Jakarta

Simatupang, S. 1997. Pengaruh pemupukan Boraks terhadap pertumbuhan dan Mutu tanaman Sayuran. Jurnal Hortikultura 6 (5) : 456-469

Sudjijo, M. Dan N. Saipinus. 1995. Pengujian varietas kubis bunga yang sesuai untuk ekspor. Jurnal Hortikultura 5 (1) : 102-105

Suprihatno. B, Daradjat. AA, Satoto, Baehaki. S.E, I.N.Widiarta, Agus. S.S, Dewi. I, Ooy. S.L dan Sembiring. H. 2009. Deskripsi Varietas Padi. Balai Besar Penelitian Tanaman Padi Badan Penelitian dan Pengembangan Pertanian Departemen Pertanian

Sutoyo, 2001. Morfologi dan Klasifikasi Tanaman Padi. http// mukegile08. wordpress.com/ 2011/ 06/ 08/ morfologi-dan-klasifikasitanaman-padi/Diakses 2 Mei 2012

Tarigan. EE, Ginting. J dan Meiriani. 2013. Pertumbuhan dan Produksi Beberapa Varietas Padi Gogo Terhadap Pemberian Pupuk Organik Cair. Jurnal 
Agroekoteknologi. Volume 2, Nomor 1. hlm : 113-120

Trias Sitaresmi, Rina H. Wening, Ami T.

Rakhmi, Nani Yunani, dan

Untung Susanto. 2013.

Pemanfaatan Plasma Nutfah Padi

Varietas Lokal dalam Perakitan

Varietas Unggul. Iptek Tanaman

Pangan, Vol. 8 NO. 1

Wingin G. 1976. Buginese Agriculture in Tidal Swamps of South Sumatera. Lembaga Pusat Penelitian Pertanian. Bogor

Yoshida, T., A. Zubair, S. Rosniawaty, dan R. Setiamihardja. 2009. Genetic background of Indonesia rice germplasm and the relationship to performance and eating quality. Jpn. J. Crop. Sci. 78: 335-343.

Yulina, N. 2020. Uji 14 Genotipe Padi Lokal Kab. Kuantan Singingi Terhadap Tinggi Tanaman, Umur Panen, Jumlah Anakan, dan Berat Panen. Skripsi Program Studi Agroteknologi. Fakultas Pertanian. UNIKS 
